\title{
Older adults with physical disabilities: vulnerabilities relative to the body, the physical and social environment
}

\author{
Idosos com deficiência física: vulnerabilidades em relação ao corpo, ambiente físico e social
}

Ancianos con discapacidades físicas: vulnerabilidades en relación con el cuerpo, el entorno físico y social

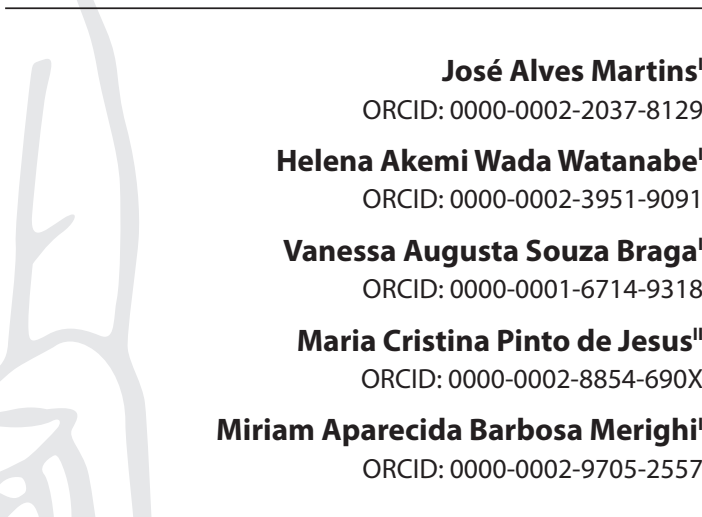

'Universidade de São Paulo. São Paulo, São Paulo, Brazil. "Universidade Federal de Juiz de Fora. Juiz de Fora,

Minas Gerais, Brazil.

How to cite this article: Martins JA, Watanabe HAW, Braga VAS, Jesus MCP, Merighi MAB. Older adults with physical disabilities: vulnerabilities relative to the body, the physical and social environment. Rev Bras Enferm 2020;73(Suppl 3):e20190175. doi: http://dx.doi.org/10.1590/0034-7167-2019-0175

Corresponding author: José Alves Martins E-mail: profzefisio@gmail.com

EDITOR IN CHIEF: Dulce Barbosa ASSOCIATE EDITOR: Hugo Fernandes

Submission: 03-09-2019

Approval: 08-28-2019

\section{ABSTRACT}

Objective: to understand the vulnerabilities of older adults with physical disabilities regarding their body, physical and social environments. Method: this was a qualitative study based on Alfred Schütz' social phenomenology, with 15 older adults with physical disability from Cuiabá, state of Mato Grosso, Brazil. Open-ended questionnaires were administered to the participants in 2017. The units of meaning that emerged were organized into thematic categories. Results: physical decline, associated with the permanence of environmental and social barriers intensified the vulnerabilities of older adults. Gaps in health services are mitigated by informal social support networks and access to work was a form of social inclusion. Final considerations: vulnerabilities in the old age of persons with physical disabilities did not reside only in the body dimension, but also the physical and social environment, countering healthcare models based on the logic of reverting their dysfunctional body.

Descriptors: Disabled Persons; Aged; Vulnerable Population; Health Services; Qualitative Research.

\section{RESUMO}

Objetivo: compreender as vulnerabilidades de pessoas idosas com deficiência física em relação ao corpo ambiente físico e social. Método: estudo qualitativo fundamentado na fenomenologia social de Alfred Schütz, com 15 pessoas idosas com deficiência física, de Cuiabá, Mato Grosso, Brasil. Os depoimentos foram obtidos em 2017, por meio de entrevista com questões abertas. As unidades de significado que emergiram foram organizadas em categorias temáticas. Resultados: evidenciou-se que o avanço do declínio físico, associado à permanência das barreiras ambientais e sociais, intensificou as vulnerabilidades da pessoa idosa. As lacunas dos serviços de saúde são atenuadas pela rede informal de apoio social, e o acesso ao trabalho constituiu um modo de inclusão social. Considerações finais: as vulnerabilidades na velhice da pessoa com deficiência física não residem apenas na dimensão corporal, mas também no ambiente físico e social, contrapondo-se os modelos de saúde baseados na lógica da reversão do corpo disfuncional.

Descritores: Pessoas com Deficiência; Idoso; Vulnerabilidade em Saúde; Serviços de Saúde; Pesquisa Qualitativa.

\section{RESUMEN}

Objetivo: Entender las vulnerabilidades de ancianos con discapacidades físicas en relación con su cuerpo, el entorno físico y social. Método: Estudio cualitativo basado en la fenomenología social de Alfred Schütz, con 15 ancianos con discapacidad física, de Cuiabá, Mato Grosso, Brasil. Se obtuvieron los testimonios en 2017, a través de entrevistas con preguntas abiertas. Las unidades de significado que surgieron fueron organizadas en categorías temáticas. Resultados: se evidenció que el avance del deterioro físico, asociado con la permanencia de las barreras ambientales y sociales, intensificó las vulnerabilidades de los ancianos. Las brechas en los servicios de salud son mitigadas por la red informal de apoyo social, y el acceso al trabajo constituye un modo de inclusión social. Consideraciones finales: las vulnerabilidades en la tercera edad de personas con discapacidades físicas residen no solo en la dimensión corporal, sino también en el entorno físico y social, contraponiendo los modelos de salud basados en la lógica de la reversión corporal disfuncional.

Descriptores: Personas con Discapacidad; Anciano; Vulnerabilidad en Salud; Servicios de Salud; Investigación Cualitativa. 


\section{INTRODUCTION}

Disability is part of the human condition, and according to the World Health Organization, almost everyone will be temporarily or permanently impaired at some point in life. Those who survive to old age will face increasing difficulties with functioning ${ }^{(1)}$.

Currently, over a billion people worldwide have some form of disability, of which approximately 190 million experience significant physical difficulties in functioning, with a growing trend due to population aging and increases in chronic health conditions $^{(1)}$. In Brazil, $6.7 \%$ of the population over the age of 18 years live with some type of disability and $17.2 \%$ have some type of functional limitation. Persons with disabilities, defined as those with great difficulties to see, hear, and/or walk/climb up stairs, are concentrated in the 60 or older age group, corresponding to $37.8 \%$ of the total disabled population. These are older adults who experience significant levels of impairment and severity ${ }^{(2)}$.

Different biological, physiological and neurological factors are involved in the aging process, which can result in the natural and gradual decline of the senses and reduced functional capacity ${ }^{(3)}$. Thus, living a long life with a disability, considering the physical dimension implies being subject to important cumulative impacts on their health conditions, because both disability and advanced age impact the functional capacity of older adults, as it can mean the aging of a functionally limited body.

In this context, physical disability coupled with the aging process brings daily difficulties for older adults, which may lead to dependence in performing activities of daily living, such as hygiene, eating, leisure and work, which can generate feelings of outrage and suffering in these individuals ${ }^{(4)}$. In addition to limitations regarding activities of daily living, persons with disabilities face various obstacles, including attitudinal, environmental and institutional barriers, which prevent their full participation on an equal basis in all aspects of life. Older adults with disabilities are often those who are most negatively impacted ${ }^{(5)}$.

Difficulties experienced by older adults with physical disabilities, which is the focus of the present study, can place them in situations of vulnerability. Understanding vulnerability as an intrinsic trait of the human condition, vulnerability considers the frailty and finitude of individuals and encompasses individual, social and programmatic dimensions ${ }^{(6)}$. The programmatic dimension reflects how institutions translate health policies into actions for older adults with physical disabilities.

Shedding light on the meaning of situations experienced by older adults with physical disabilities from their point of view, based on the intersubjective relationships that occur in the physical and social environment, can expand the visibility of knowledge within the scope of healthcare practices and policies about this double vulnerability, being an older adult and living with a physical disability. The research question was as follows: What is the daily life of older adults living with physical disabilities in terms of the body dimension, the physical and social environment?

\section{OBJECTIVE}

To understand the vulnerabilities of older adults with physical disabilities regarding their bodies, physical and social environment.

\section{METHODS}

\section{Ethical aspects}

The present study was approved by the Research Ethics Committee of the Public Health School at the University of São Paulo and followed all guidelines set forth in Resolution no 466/2012 of the Brazilian National Health Council/Ministry of Health ${ }^{(7)}$.

\section{Theoretical-methodological framework}

This survey was based on the social phenomenology of Alfred Shüt ${ }^{(8-9)}$, who adopted assumptions that contribute to the discussion of the results. Social reality considered within the scope of human interactions is called the social world. In this world, intersubjectivity that results from the context of experiences allows for the signification of daily life situations. The meaning that emerges from social relationships is understood based on the stock of mundane knowledge that places people in the social world. Even in different biographic situations, humans select and interpret common objects identically, when they are aimed to reach similar purposes. This allows for the feeling of social belonging and occurs due to the congruence of the system of social relevance that indicates reciprocity of perspectives.

\section{Type of study}

This was a qualitative study based on Alfred Schütz' social phenomenology. It abided by the steps recommended by the Consolidated Criteria for Reporting Qualitative Research (COREQ) ${ }^{(10)}$.

\section{Research setting}

The study was carried out in the Association for persons with disability of Mato Grosso (or Associação Matogrossense de Deficientes, in Portuguese), a philanthropic entity located in the metropolitan region of Cuiabá, state of Mato Grosso, Brazil. The aim of this association is to disseminate information and proposals, monitoring and controlling public policy directed at persons with disabilities, in addition to promoting cultural, sport and scientific exchanges. According to its statute, all duly registered individual with any type of proven disability and who are willing to contribute so that the entity can achieve its objectives can become a member. With approximately 6,000 active associates and, despite its headquarters being located int he capital city, this association has statewide reach, with various branches in cities throughout Mato Grosso(11).

\section{Source of data}

Fifteen people who met the inclusion criteria participated in the survey: community-dwelling older adults 60 years or older living with a congenital physical disability or one acquired until the age of 40 years. Older adults with disabilities due to chronic conditions inherent to aging were excluded, as these are considered different types of experiences. Furthermore, although there were persons over the age of 70 in the registry of the Association for Persons with Disability of Mato Grosso, none of them were found alive or in physical or cognitive conditions to be interviewed. 


\section{Data collection}

The participants were approached by the main researcher - at the time a doctoral candidate - during two visits to the Association for Persons with Disabilities of Mato Grosso, where some group activities and workshops were developed with the associates to promote proximity with possible research participants. The individuals who met the inclusion criteria were invited to participate and informed about the objectives of the study, their right to abandon the study at any time, in addition to signing an informed consent form.

Participant selection was intentional; interviews were scheduled via telephone calls, based on the inclusion criteria established and the home addresses of possible participants as recorded in the member registry.

Data collection took place using an open-ended questionnaire, which was administered by the main researcher and lasted an average of 1 hour and 50 minutes, between July 2016 and June 2017, at the participants' homes. The following guiding questions were used: Please tell me about your experience of aging with a physical disability. What is your daily life like? In addition to these questions, personal data was also gathered.

The interviews were ended when no new themes emerged and the significant content that resulted from the answers was considered enough to answer the research objective and questions. The total of interviews generated data that showed the depth, breadth, and diversity of the process of understanding the studied object, as recommended by qualitative research guidelines ${ }^{(12)}$. All the interviews were included and identified using numbers preceded by the letter $\mathrm{P}$ (for participant). None of the participants left the study and therefore, there was no sample loss.

\section{Organization and analysis of results}

The interviews were recorded on an MP4 audio device after obtaining the participants' consent and analyzed based on the steps suggested by Alfred Schütz' social phenomenology ${ }^{(13)}$. First, the interviews were transcribed and then the researchers conducted an in-depth reading of the content to identify units of meaning. Next, these units were organized into four thematic categories. The first two expressed the vulnerabilities relative to the body and physical and social environment from the perspective of older adults living with physical disabilities. The other two categories regarded the search for informal social support networks to overcome limitations of healthcare services and insertion in the labor market as an opportunity for social belonging. The categories were interpreted based on the theoretical and methodological framework and the literature on the topic.

\section{RESULTS}

Most participants were wheelchair users, female, Catholic, single, white, with low education level, acquired disability, a mean family income of 2.8 monthly minimum wages, and were between the ages of 60 and 69 (mean 62.8) and had a mean time of experience with disability of 47.9 years. Most worked in the formal labor market, although some were retired and others had informal jobs.

\section{Decline in functional capacity associated with physical and social barriers}

The interviews revealed that older adults with physical disabilities experienced reduced functional capacity that results in reduced mobility and quality of life:

[...] For a physically normal person, it's hard to grow old because
of your capacity, which is reduced. Now imagine someone with
a disability who already has physical problems! (P1)

When I was young, it was different, but with old age, what most changes are the sequelae that worsen in your body [...] today I am dependent for almost everything. This is very hard! (P2)

[...] But now, 62 years old, I'm no longer able! [...] I have no more strength or will, I am slower in everything I do. (P5)

It's been 44 years in this wheelchair and now I can't take it anymore. [...] as we age, the parts of the body that worked stop working [...] this causes much suffering! (P8)

Time has gone by and I have lost my strength! I can't get out of from bed by myself [...] I used to be able to do all that, but now older, I no longer can. (P12)

In addition to reduced functional capacity, older persons with physical disabilities mentioned barriers relative to accessibility, which hinder social participation and generate physical and emotional suffering:

[...] Today I think it's better to stay home than going out, because on the street, it's impossible to go with the wheelchair [...]. Some streets don't have sidewalks and it's dangerous in the middle of the street with a wheelchair. (P3)

[...] I went to the doctor and there was no elevator, at the clinic. I stayed there for a long time until two young men came by and carried me up the stairs. (P6)

[...] Because bathrooms usually have very narrow doorways and I can't go in with the wheelchair. (P7)

[...] / encounter lots of barriers even when going to the doctor [...] Let me tell you, growing old in Brazil with a disability is a very difficult chore! (P8)

[...] / am very forsaken. [...] / am not strong enough anymore to push my wheelchair down an unpaved street with no sidewalks. (P13)

\section{Unmet needs by the healthcare service network}

Participants revealed that when seeking healthcare services, they did not receive care that met their needs. These mismatches between older adults with physical disabilities and healthcare services can be seen in the following excerpts:

[...] When I'm in a lot of pain, I medicate myself. [...] It's been a year since l've updated my prescription. (P3)

It's been a year without physical therapy [...] they discharged me because my case is chronic, but it made a big difference! (P4) 
[...] Rehabilitation services don't pick up people with disabilities at their homes [...] they don't provide families with orientation so that they can provide continuity of care at home [...] they don't accept chronic patients. (P10)

[...] The last time I went to the hospital, I was sent back home! They gave me an IV sitting in a chair in the hallway, but it made me sicker instead of better! I have a bedsore and cannot sit on hard chairs. [...] they do not give priority to persons with disability. (P2)

[...] I was afraid of drowning because the physical therapist wouldn't go in the pool to take care of me, just gave me instructions from outside the pool. [...] / simply gave up! (P1)

[...] Professionals do not understand disability. [...] The truth is not everyone likes to care for persons with disability because it's a lot of work. (P8)

\section{Informal social support network}

According to the participants, the needs that were not met by the formal healthcare system are minimized by the informal social support network, built through daily social interactions:

[...] I felt very sick here at home, I passed out, and when I woke up, I sent a messagetomynext-doorneighborandhecameoverimmediately!(P13)

I don't have a caregiver, but I asked my neighbor to stay with me during my tests and in surgery. (P11)

[...] The pastor went to the rehabilitation center to request a wheelchair for me. [...] sometimes, when I'm very sad and alone, my neighbor comes over and we vent with one another. (P2)

My family always helps [...] when I feel sick, I call them and a family member always comes over. (P8)

[...] after my parents passed away, I needed help. I often need help because I am no longer able to do things on my own. (P9)

The neighbor's boy helps me out [...] when I ask him, he goes to the market, he brings me food, buys my bread, sweeps the yard, things like that! (P4)

\section{Social inclusion through work}

According to the participants, the need to belong to a group makes them consider accessing the labor market as a way of achieving social inclusion:

[...] Before this job, I thought nobody would want to have an employee with a disability. [...] It gave me a lot of energy, the will to learn to do, to feel useful and valued. [...] it gave me strength to recover physically. [...] To work is to be part of society. (P1)

[...] To me, working means exercising the mind, it means being in society, living with others, learning more and having more knowledge [...] because if people with disabilities work, they can earn their own money and live a comfortable life. (P2)

[...] Work helps me because I'm a part of society and am also developing some activity, even in a wheelchair, l am being useful. This makes me feel great! (P5)
My job was a way of leaving the house and getting to know other people who also had disabilities and this helped me overcome my situation. [...]Work was important in my life! (P9)

Based on myjob, my desire to have my own family grew and l became more confident. My satisfaction and self-esteem improved. (P10)

[...] I still work today and I could retire already, but I haven't! [...] When you work, people recognize your value and this is priceless. (P11)

\section{DISCUSSION}

Analyzing the results based on the social phenomenology of Alfred Schütz allows for an understanding that the aging of older adults with physical disability is guided by a stock of past experiences and present meanings, historically and culturally produced in the social group, shared in the daily lives of these persons. This stock of knowledge, coupled with lived experiences, leads them to signify their physical condition in the microstructural context of socio-environmental relationships.

The participants mentioned difficulties to carry out daily activities due to reduced mobility affected by the disability and made more severe with age. Mobility is one of the key components of independent functionality. However, the progression of physical decline leads to decreased functional abilities that limit opportunities of individuals to participate in social life, occurring a vicious downward spiral, loss of independence and increased vulnerability ${ }^{(14)}$.

Physical decline and progressive disability that increases with age, associated with a pre-existing physical disability, have been discussed in the literature. In an Australian study with ten older adults with physical disability, the participants reported negative changes in their skills, disabilities, and health conditions as they grew older, which increased dependence and limitations when carrying out their daily activities. The study emphasizes that biological aging often begins at earlier life phases among persons with disabilities ${ }^{(15)}$.

The interviews show that, within the scope of the present study, the physical and social environments did not change to favor the inclusion of older adults with disabilities according to their needs. Recurring obstacles to the adequate use of public devices were mentioned by the participants, such as broken and unkept sidewalks, narrow doorways inaccessible to wheelchair users, absence of elevators, and inaccessible bathrooms.

The presence of barriers to accessibility presents broad implications in the social life of those interviewed, with impact on their mobility, reduced social participation, and reduced quality of life. A similar result was found in a study conducted with persons with physical disabilities in London, which showed that difficulties in accessing public transport generated anxiety and social isolation, in addition to physical injuries caused by extreme push force used by individuals to adapt to the adverse conditions of urban mobility ${ }^{(16)}$.

The participants also mentioned architectural barriers to public and private healthcare services, with restricted access, hindering mobility and the possibility of safely entering these places, which contributes to the discontinuance of consultations, tests and other medical procedures. A study developed in the capital of the state of Paraíba, Brazil, evaluated the buildings of 90 Basic 
Health Units and identified that only $47.8 \%$ had an access ramp, and of these, $30 \%$ presented maximum inclination and $32.2 \%$ had anti-slip coating. In $28.9 \%$, patients had to access the unit using a staircase with no handrail, and $6.7 \%$ had anti-slip coating. And in only $17.8 \%$ did the sliding doors have lowered thresholds. The results indicate that the units' infrastructure does not correspond to the needs of persons with disabilities, thus hindering access to healthcare services ${ }^{(17)}$.

In the United States, a study analyzed access to healthcare services by persons with disabilities and showed that those with greater physical limitations were especially prone to having problems accessing health care and not having their needs met $^{(18)}$. Factors such as uneven access to buildings and medical equipment, poor signage, narrow doorways, internal steps, inadequate bathroom facilities and inaccessible parking areas create barriers to healthcare services that make it hard for individuals with disabilities to attend appointments and tests that could prevent health problems or improve their health condition ${ }^{(1)}$.

The assumptions of Alfred Schütz' social phenomenology affirm that the social insertion of individuals is constructed based on the universe of their experiences, which corresponds to the singular space of human relationships. This space is not limited to the physical environment, but encompasses the social interactions of the mundane world ${ }^{(9)}$. The results of the present study show that the individual limitations of older adults with disabilities are enhanced by the existing barriers in this world, which restrict mobility because of architectural issues or lack of access to goods and services. This limit makes participants value social interactions within their everyday lives, including in healthcare services.

The older adults with physical disabilities, mentioned numerous examples of how healthcare services directed at rehabilitation were lacking in terms of the principle of providing comprehensiveness of care to this segment of the population. The participants said that they had lost access to treatment under the service's allegation that their chronic condition could not be reversed. This protocol forces individuals to adjust to their own disabilities and limitations because of lack of health care that meets their needs. Excluding older adults with physical disabilities from health services under the allegation of chronicity goes against the findings of a study in the United States that indicated the importance of interventions that address the aging of these individuals, especially when they present associated chronic comorbidities ${ }^{(19)}$.

A qualitative study that associated disability, violence, and poverty among adults and young older adults (60 years old) classified the way social practices created inequalities and social exclusion as structural violence. These practices limit participants' access to education, health, and employment. Shedding light on how the context and culture shape the experience of living with disability in poverty indicates that policies that do not take into account these aspects are incapable of meeting the needs of those they were created for ${ }^{(20)}$.

In the present study, the participants did not mention primary healthcare level activities aimed at older adults with physical disabilities. One of the principles of primary health care is to enable universal and ongoing access to quality healthcare services. The access of older adults with physical disabilities to the healthcare system should provide an opportunity for participating in life in society, independence, in addition to ensuring the principle of equality ${ }^{(21)}$.

It is worth emphasizing that a study carried out in Canada explored how family physicians perceived primary care for persons with mobility disabilities and found that they received the same level of care as other persons without disabilities, thus ignoring their unique needs ${ }^{(22)}$. This reality was also registered in Brazil, in a study that investigated older adults with physical disabilities caused by a stroke. Primary healthcare services provided these individuals only with drug prescription renewals and did not provide orientation about issues they deemed necessary relative to their condition ${ }^{(23)}$.

Thus, it is necessary to break with the current fragmented model of healthcare services, based on hierarchic actions, especially rehabilitation services, in which tertiary level is given privilege, with a predominance of technological densities, one-off and individual actions, a doctor-centered approach and actions on demand. This healthcare model is a barrier to maintaining mobility and social participation of older adults with physical disabilities, and therefore, reformulations are necessary with emphasis on the need of recognizing the value of survival of older adults with physical disabilities, with a minimum level of independence and autonomy ${ }^{(24)}$. Therefore, it is important to create space for innovative actions and intensify dialogue to help overcome the hegemonic model in light of the principle of comprehensiveness of care at the different levels of health care.

The group of older adults with physical disabilities establishes the collective self-interpretation of common aspects experienced regarding healthcare services and identify gaps that hinder the reciprocity between both of their perspectives. Such reciprocity leads humans to seize objects known by them and by others, regardless of biographical situation and individual conditions ${ }^{(8)}$.

The limitations of healthcare services to meet the singular needs of these individuals make them seek out the support they need in informal networks. The informal social support network, which consists of mutual and long-lasting bonds of cooperation, formed through daily social relationships, composed by family members, neighbors, associations, churches, etc., was mentioned as an alternative to meeting their care needs. This reality was also identified in a study with individuals with physical disability in João Pessoa, Paraíba, Brazil, in which the respondents said that their support networks were mainly composed of family members (parents, siblings, children, partners) and individuals outside of the family (friends and neighbors). The support network also helped them access services and participate in social groups ${ }^{(25)}$.

According to the social phenomenology of Alfred Schütz, the reality of daily life is shared with others during face-to-face relationships, providing access to reciprocal meanings ${ }^{(8)}$. Thus, the social group, spontaneously instituted and not guided by formal rules, is strengthened with interactions conducted in the everyday world. Within informal social support networks, several levels of intersubjective exchanges occur, covering not only material support, but above all, psychophysical and social support ${ }^{(9)}$.

A study conducted in the United States showed that informal support networks are related to reduced morbidity and mortality, improved psychological well-being and reduced health risk behaviors among older adults ${ }^{(26)}$. On the other hand, greater risk 
of mortality was associated with more restricted social support networks ${ }^{(27)}$ A study conducted with 206 older adults in Portugal showed that being part of an informal social support network is a protection factor against poor social and health conditions and can have positive effects on their well-being ${ }^{(28)}$.

Even when considering the positive influence of informal social support networks on the health of participants, formal networks and the State still has its responsibility in providing care to older adults with physical disabilities. Health services must promote equality and access, in addition to ensuring treatment options that take into account the vulnerabilities and potentials inherent to persons with disabilities, especially as they grow older. When health services consider and care for the needs of persons with disabilities, they can improve health behaviors, prevent secondary conditions, delay the progression of disability, or, via early detection of diseases, allow for early interventions that can improve health outcomes ${ }^{(29)}$.

Despite the physical-functional limitations, social and environmental barriers, the capacity to work was associated by the participants with their social inclusion. Several studies provide scientific evidence about the importance of work for adults and older adults living with disabilities ${ }^{(15,30-31)}$. In Australia, a qualitative study about the experience of older adults with disabilities showed that, among other adaptive strategies, paid or voluntary employment was crucial to the positive perception of their social roles $^{(15)}$. A study conducted with 20 persons with physical disabilities and hearing impairments who worked in a factory in Santa Catarina, Brazil, showed that the participants considered work to be a generator of social inclusion, self-worth, financial independence, improved self-esteem, and the possibility of being considered an equal of those without disabilities ${ }^{(30)}$.

In an investigation that qualitatively analyzed the meaning of employment of individuals with disabilities due to spinal cord injury, in six European countries, showed that regardless of social status, the participants considered their job very important. Three main functions of employment according to the participants were identified: creating a personal and collective identity and social recognition; structuring time; and an important social arena that facilitates interaction among people ${ }^{(31)}$.

As shown in the results of the present study, inclusion through work allowed the participants to improve their quality of life, both in socioeconomic and individual aspects. Work was considered to be an opportunity for social belonging. Through their jobs, they were able to share socially constructed meaning based on the singularity of their condition. Belonging does not depend on socially accepted knowledge. Even without being part of a specific social group, humans are able to grasp the general rules and associate the meaning of a certain situation in the context of the present experience. All it takes is for individuals to find in this experience some pre-knowledge about this situation, in addition to the criteria for its constitution ${ }^{(9)}$.

Changing the physical and social environment, in accordance with the law, is essential to allow people with disabilities to live independently in their communities, make their own choices and play an active role in society. Reducing the vulnerabilities of persons with disabilities includes ensuring autonomy and the capacity of exercising their rights in the areas of health, work, education, and infrastructure, with equal conditions as those given to other people $e^{(5,32)}$.

\section{Limitations of the study}

This was a qualitative study conducted with members of an association for persons with disability in a city of the Center-West region of Brazil and therefore, its results cannot be generalized. Other contexts can present aspects that were not covered in the present investigation.

\section{Contributions to the area of nursing, health, and public policy}

The emphasized aspects of the vulnerability of older adults with physical disabilities regarding the body and the physical and social environment can help in the adjustment of public policies and health services offered to this segment of the population.

A care model based on the modification of physical and social environments can add quality of life to the lives of persons with physical disabilities, despite the consequences of the predictable progression of the biopsychosocial decline inherent to aging. When it comes to ensuring legal rights, the healthcare service network must incorporate the principles of the Brazilian Inclusion Law. Policies and health programs for older adults must be coordinated to take into account the cross-sectionality between aging and physical disability and how to foster means so that society can ensure that programs and facilities meet the needs of a population that ages.

In terms of the unmet needs in the healthcare services provided to older adults with physical disabilities, there is a need for investing in healthcare professionals, especially physical therapists and nurses, in actions that focus on the singularities of these people, especially in basic health units - the first point of entry into the Brazilian healthcare system.

\section{FINAL CONSIDERATIONS}

The present study found that the progression of physical decline associated with the permanence of environmental and social barriers intensifies the vulnerabilities of older adults with physical disabilities. Unmet needs in the healthcare network are mitigated by informal social support networks, and access to employment represented a form of social inclusion. These results should alert health professionals to consider the vulnerabilities and potentials inherent to persons with disability, especially as they age.

With the goal of expanding the scope of knowledge about the singularities of individuals with physical disabilities, the results of the present study should be discussed within the scope of research, health care, and undergraduate and graduate health programs, with emphasis to physical therapy and nursing.

\section{ACKNOWLEDGEMENTS}

Thanks to the National Council for Scientific and Technological Development (CNPq) for granting a Research Productivity Scholarship to one of the authors, which helped finance this publication. 


\section{REFERENCES}

1. World Health Organization. Disability and health: fact sheet reviewed [Internet]. Geneva: WHO; 2016 [cited 2019 Feb 28]. Available from: http://www.who.int/mediacentre/factsheets/fs352/en/

2. Instituto Brasileiro de Geografia e Estatística. Panorama nacional e internacional da produção de indicadores sociais: grupos populacionais específicos e uso do tempo [Internet]. Rio de Janeiro; 2018 [cited 2019 Feb 28]. Available from: https://biblioteca.ibge.gov.br/visualizacao/ livros/liv101562.pdf

3. Harridge SDR, Lazarus NR. Physical Activity, Aging, and Physiological Function. Physiology [Internet]. 2017 [cited 2019 Feb 28];32:152-61. Available from: https://www.ncbi.nlm.nih.gov/pubmed/28228482

4. Valença TDC, Santos WS, Lima PV, Santana ES, Reis LA. Physical disability in old age: a structural study of social representations. Esc Anna Nery [Internet]. 2017 [cited 2019 Feb 28];21(1):e20170008. Available from: http://www.scielo.br/pdf/ean/v21n1/en_1414-8145-ean-2101-e20170008.pdf

5. United Nations. Committee on the rights of persons with disabilities [Internet]. New York; 2018 [cited 2019 Feb 28]. Available from: https:// www.ohchr.org/en/issues/disability/pages/disabilityindex.aspx

6. Cestari VRF, Moreira TMM, Pessoa VLMP, Florêncio RS, Silva MRF, Torres RAM. The essence of care in health vulnerability: a Heideggerian construction. Rev Bras Enferm [Internet]. 2017 [cited 2019 May 24];70(5):1112-6. Available from: http://www.scielo.br/pdf/reben/ v70n5/0034-7167-reben-70-05-1112.pdf

7. Ministério da Saúde (BR). Resolução 466 de 12 de dezembro de 2012: Aprova diretrizes e normas regulamentadoras de pesquisas envolvendo seres humanos [Internet]. 2012 [cited 2019 Feb 28]. Available from: http://conselho.saude.gov.br/resolucoes/2012/reso466.pdf

8. Schütz A. El problema de la realidade social: escritos I. Buenos Aires: Amorrotu; 2015.

9. Schütz A. A construção significativa do mundo social: uma introdução à sociologia compreensiva. 1st ed. Trad. Tomas da Costa. Petrópolis: Vozes; 2018

10. Tong A, Sainsbury P, Craig J. Consolidated criteria for reporting qualitative research (COREQ): a 32-item checklist for interviews and focus groups. Int J Qual Health Care [Internet]. 2007 [cited 2019 Feb 28];19(6):349-57. Available from: https://academic.oup.com/intqhc/ article/19/6/349/1791966

11. Associação Matogrossense de Deficientes (AMDE) [Internet]. Cuiabá; 2019 [cited 2019 May 2019]. Available from: www.amdemt.org.br

12. Minayo MCS. Amostragem e saturação em pesquisa qualitativa: consensos e controvérsias. Rev Pesq Qual [Internet]. 2017 [cited 2018 Feb 28];7;5(7):1-12. Available from: https://edisciplinas.usp.br/pluginfile.php/4111455/mod_resource/content/1/Minayosaturacao.pdf

13. Martins JA, Merighi MAB, Jesus MCP, Watanabe HAW. Aging with physical disabilities: experience intersected by stigma, social isolation and finitude. Esc Anna Nery [Internet]. 2018 [cited 2019 Feb 28];22(4):e20180128. doi: 10.1590/2177-9465-ean-2018-0128

14. Portegijs E, Rantakokko M, Viljanen A, Sipilä S, Rantanen T. Identification of older people at risk of ADL disability using the Life-Space Assessment: a longitudinal cohort study. J Am Med Dir Assoc [Internet]. 2016 [cited 2019 Feb 28];17(5):410-4. Available from: https://www. ncbi.nlm.nih.gov/pubmed/26805752

15. Cooper M, Bigby C. Cycles of adaptive strategies over the life course. J Gerontol Soc Work [Internet]. 2014 [cited 2019 Feb 28];57(5):421-37. Available from: https://www.tandfonline.com/doi/abs/10.1080/01634372.2013.875972?journalCode=wger20

16. Velho R, Holloway C, Symonds A, Balmer B. The effect of transport accessibility on the social inclusion of wheelchair users: a mixed method analysis Cogitatio [Internet]. 2016 [cited 2019 Feb 28];4(3):24-35. Available from: https://www.cogitatiopress.com/socialinclusion/article/view/484/484

17. Martins KP, Costa TF, Medeiros TM, Fernandes MGM, França ISX, Costa KNFM. Internal structure of Family Health Units: access for people with disabilities. Ciênc Saúde Coletiva [Internet]. 2016 [cited 2019 Feb 28]; 21(10):3153-3160. Available from: http://www.scielo.br/pdf/csc/ v21n10/en_1413-8123-csc-21-10-3153.pdf

18. Horner-Johnson W, Dobbertin K, Lee JC, Andresen EM. Disparities in health care access and receipt of preventive services by disability type: analysis of the Medical Expenditure Panel Survey. Health Serv Res [Internet]. 2014 [cited 2019 Feb 28];49(6):1980-99. Available from: https:// www.ncbi.nlm.nih.gov/pubmed/24962662

19. Smith AE, Molton IR, Jensen MP. Self-reported incidence and age of onset of chronic comorbid medical conditions in adults aging with long-term physical disability. Disabil Health J [Internet]. 2016 [cited 2019 Feb 28];9(3):533-8. Available from: https://www.ncbi.nlm.nih.gov/ pubmed/27009420

20. Neille J, Penn C. The interface between violence, disability, and poverty: stories from a developing country. J Interpers Violence [Internet]. 2015 [cited 2019 Feb 28];2015;1-25. Available from: https://www.ncbi.nlm.nih.gov/pubmed/26228916

21. Girondi JBR, Santos SMA, Nothaft SCS. Outlooks on disability in older adults: health vulnerabilities. Rev Enferm UERJ [Internet]. 2015 [cited 2019 Feb 28];23(2):172-7. Available from: http://www.facenf.uerj.br/v23n2/v23n2a05.pdf

22. McMillan C, Lee J, Milligan J, Hillier LM, Bauman C. Physician perspectives on care of individuals with severe mobility impairments in primary care in Southwestern Ontario, Canada. Health Soc Care Community [Internet]. 2016 [cited 2019 Feb 28];24(4):463-72. Available from: https:// www.ncbi.nlm.nih.gov/pubmed/25809600 
23. Carvalho-Pinto BPB, Faria CDCM. Health, function and disability in stroke patients in the community. Braz J Phys Ther [Internet]. 2016 [cited 2019 Feb 28];20(4):355-66. Available from: http://www.scielo.br/pdf/rbfis/v20n4/1413-3555-rbfis-bjpt-rbf20140171.pdf

24. Mitre SM, Andrade EIG, Cotta RMM. Attendance and the change in the praxis of rehabilitation: a study of Centers of Reference in Rehabilitation in the network of the Unified Health System in Belo Horizonte, State of Minas Gerais, Brazil. Ciênc Saúde Coletiva [Internet]. 2013 [cited 2019 Feb 28];18(7):1893-902. Available from: http://www.scielo.br/pdf/csc/v18n7/04.pdf

25. Holanda CMA, Andrade FLJP, Bezerra MA, Nascimento JPS, Neves RF, Alves SB, Ribeiro KSQS. Support networks and people with physical disabilities: social inclusion and access to health services. Ciênc Saúde Coletiva [Internet]. 2015 [cited 2019 Feb 28];20(1):175-84. Available from: http://www.scielo.br/pdf/csc/v20n1/1413-8123-csc-20-01-00175.pdf

26. Beach SR, Schulz R, Sneed R. Associations between social support, social networks, and financial exploitation in older adults. J Appl Gerontol [Internet]. 2018 [cited 2019 Feb 28];11:1-22. Available from: https://www.ncbi.nlm.nih.gov/pubmed/27255685

27. Santini ZI, Koyanagi A, Tyrovolas S, Haro JM, Fiori KL, Uwakwa R, et al. Social network typologies and mortality risk among older people in China, India, and Latin America: A 10/66 Dementia Research Group population-based cohort study. Soc Sci Med [Internet]. 2015 [cited 2019 Feb 28];147(1):134-43. Available from: https://www.ncbi.nlm.nih.gov/pubmed/26575604

28. Maia CML, Castro FV, Fonseca AMG, Fernández MIR. Redes de apoio social e de suporte social e envelhecimento ativo. Rev Infad Psicol [Internet]. 2016 [cited 2019 Feb 28];1(1):293-04. Available from: http://www.infad.eu/RevistalNFAD/OJS/index.php/IJODAEP/article/ view/279/182

29. Okoro CA, Hollis ND, Cyrus AC, Griffin-Blake S. Prevalence of disabilities and health care access by disability status and type among adults: United States, 2016. MMWR [Internet]. 2018 [cited 2019 Feb 28];67(32);882-87. Available from: https://www.cdc.gov/mmwr/volumes/67/wr/ mm6732a3.htm

30. Perlin A, Gomes C, Kneipp J, Frizzo K, Rosa L. Inclusão de pessoas com deficiência no mercado de trabalho: um estudo numa empresa do setor cerâmico. Desenv Questão [Internet] 2016 [cited 2019 Feb 28];14(34):214-236. Available from: https://www.revistas.unijui.edu.br/ index.php/desenvolvimentoemquestao/article/view/4030

31. Leiulfsrud AS, Ruoranen K, Ostermann A, Reinhardt JD. The meaning of employment from the perspective of persons with spinal cord injuries in six European countries. Work [Internet] 2016 [cited 2019 Feb 28];55(1):133-44. Available from: https://www.ncbi.nlm.nih.gov/ pubmed/27612062

32. Presidência da República (BR). Lei no 13.146, de 6 de julho de 2015. Institui a Lei Brasileira de Inclusão da Pessoa com Deficiência [Internet]. 2015 [cited 2019 Feb 28]. Available from: http://www.planalto.gov.br/ccivil_03/_Ato2015-2018/2015/Lei/L13146.htm 